\title{
RACIONALIDADE DO DIREITO E A CONDIÇÃO HUMANA: SOBRE O ENTRELAÇAMENTO ENTRE O DIREITO, POLÍTICA E MORAL
}

Luciano Braz

Silva ${ }^{1}$

\section{Resumo}

A proposta de Habermas que busca perquirir a legitimidade do Estado constitucional democrático com base nos direitos humanos visa a estabelecer uma conexão interna entre uma democracia efetiva - exercício político - e o direito. Para tanto, faz-se necessário, a formulação de um conceito político de legitimação de ordens caracterizadas pela organização do poder estatal, que segue atrelado ao direito legitimamente instituído. Considerando que esse médium da potência estatal se constitui sob a forma do direito, as ordens políticas buscam, na legitimidade reivindicada do direito, seu vigor. O presente artigo tem como foco de pesquisa examinar o déficit teórico quanto as possibilidades de implementação do exercício democrático, o reconhecimento, bem como, analisar a relação de completitude entre a política e o direito. Para tanto, o presente artigo valendo-se do pensamento de Habermas vê na figura do direito positivo moderno, a possibilidade de assimilar - via ação comunicativa - a tensão entre facticidade e validade. $O$ presente artigo voltara suas atenções ao problema central que abarca as possibilidades de reprodução social instaladas no mundo da vida, buscando perquirir a legitimidade do direito à vista da proposta estabelecida pelo ideário do Estado Democrático de Direito.

Palavras-chave: Dignidade Humana. Luta por Reconhecimento. Emancipação. Estado Democrático de Direito.

\section{INTRODUÇÃO}

Dentre as principais ideias abordadas nas obras de filosofia política e filosofia do direito apresentadas por Habermas, esse artigo selecionou algumas considerações do

\footnotetext{
${ }^{1}$ Mestre em filosofia do direito pelo Centro Universitário Eurípides de Marília (UNIVEM), com Bolsa Caps. Integrante do Grupo de Pesquisa Científicas GEP - Univem. Possui cadastro no Grupo de pesquisa - Processos político-sociais e exclusão - Unesp-Marília. Pesquisador com cadastro junto ao CONPEDI - Conselho Nacional de Pesquisa e Pós-Graduação em Direito - desde 20o9. E-mail: lubra_@hotmail.com
} 
filósofo alemão no que diz respeito a temática proposta. Nas primeiras linhas desse artigo, onde trabalhamos a interpretação e a lógica do Estado de Direito procuraremos examinar as figuras do direito e do poder político e, por conseguinte, a interligação complexa que visa a preencher, reciprocamente, as funções que se interligam uma a outra. Destacaremos que a relação entre direito e política diferencia-se da relação entre moral e direito, e a ligação entre a moral e o direito delineia-se numa relação de complementaridade assentada nas esferas de valor que se diferenciam na modernidade. Nesse sentido, identificaremos o aparelho estatal descrito a partir de um sistema organizacional do direito.

Herdeiro do hegelianismo (intersubjetividade, evolucionismo dialético) e do kantismo (universalidade, incondicionalidade, formalismo), Habermas quer encontrar razões que justifiquem - por uma obrigação incondicional, objetiva, e por um decreto moral da razão - a conduta democrática para além do caráter contingente de meras preferências ou tendências reguladas e das conversões partilhadas de uma determinada sociedade. A abordagem habermasiana procura formular uma base normativa para alimentar formas democráticas de comunidade, para além do acordo contigente. Essa base, segundo Habermas, pode encontrada nos pressupostos implícitos universais de toda interação comunicativa, dos quais sustentariam ou balizariam uma moralidade política mínima, em última análise, democrática, não regulamentada por esta ou aquela concepção, mas no campo estritamente procedimental. Isso torna central o aspecto da busca de reconhecimento, à qual Habermas dedica parte das suas considerações teóricas contemporâneas.

Dentre os assuntos abordados no corpo deste artigo, analisamos algumas questões voltadas para as perspectivas normativas de reconstrução do sistema dos direitos e dos princípios do Estado de Direito. Aqui, veremos como Habermas compreende os desafios derivados do poder social e da complexidade das sociedades modernas. Arrostamo-nos, então, com uma tensão externa entre fatos sociais e direito, ou seja, entre autocompreensão normativa do Estado de direito e facticidade social dos processos políticos. O artigo demonstrará a relação de complementaridade entre o direito e a política, bem como, seus pressupostos de validade para regularização da vida social. A questão da legitimação de um poder político estruturado na forma do Estado de direito, pode ser compreendida desde que, mediante a ótica do conceito de vol.08, nº. 01, Rio de Janeiro, 2015. pp. 350-385 351 
autonomia política dos cidadãos, fundamentado na teoria do discurso, se consiga diferenciar as figuras do poder comunicativo, produto do direito legítimo, e aqueles pertencentes ao poder administrativo, responsável pela imposição das leis. Veremos que as formas comunicativas devem interligar e satisfazer, simultaneamente, a diferentes condições de comunicação, uma vez que, se prescindirmos da organização da afluência dessas informações, poderemos nos valer do auto-entendimento ético e da fundamentação moral de regras com a finalidade de estabelecermos o equilíbrio equitativo de interesses.

Autores como Taylor e Honneth ressaltam a construção relacional da identidade, frisando as estruturas dialogais entre os sujeitos que lutam o tempo todo por reconhecimento mútuo. Tanto Taylor como Hanneth entendem que essa será a condição pela qual os sujeitos podem se desenvolver de maneiras saudáveis e autônomas. Nessa perspectiva, a compreensão e o reconhecimento da identidade (por si e pelo outro) seria a condição primeva para auto-realização. Em seu ensaio seminal sobre o multiculturalismo, Taylor afirma que o reconhecimento não é uma questão de cortesia, antes sim, trata-se de uma necessidade humana. Isso porque pessoas e grupos podem sofrer danos reais se a sociedade os representa com imagens restritivas e depreciativas.

O artigo apresentará algumas considerações de Honneth que se coadunam ao pensamento de Jügen Habermas. Para Honneth o mundo transforma e evolui-se moralmente por meio das lutas intersubjetivas por reconhecimento mútuo. É no mundo da vida que se naturalizam e se questionam tradicionais padrões de comportamento (desrespeito), deste modo, indivíduos buscam, diariamente, fazer-se reconhecidos para se auto-realizarem enquanto sujeitos de direito. A questão da distribuição é pensada por Honneth a partir de um modelo diferenciado de reconhecimento. Como já abordado, ele alega que os sujeitos lutam por bens materiais tanto para se verem considerados seres humanos de igual valor, como para verem reconhecidos seus méritos e realizações distintivos. É a partir da lógica do reconhecimento, e não simplesmente visando ao aumento de bens materiais, que os sujeitos aspirariam a práticas redistributivas. Interessa-nos frisar aqui, exatamente, a importância desse uso ético.

O presente artigo apontará a perspectiva assumidas por Habermas com relação ao agir comunicativo considerando as possibilidades do dissenso (razão instrumental) e vol.08, nº. 01, Rio de Janeiro, 2015. pp. 350-385 352 
do falibilíssimo inerentes ao mundo da vida. Tal risco se mostra muito evidente, analisando o fato da complexidade que envolve a sociedade moderna multicultural, em que as interações estratégicas são costumeiramente utilizadas pelos sujeitos. Nessa perspectiva, o artigo apontara a função do direito no pensamento de Habermas que passa a ser visto como resposta adequada ao presente questionamento. Ao perceber que a linguagem, mesmo quando utilizada comunicativamente, não tem força suficiente para assegurar a integração social, devido ao multiculturalismo e às complexidades ideológicas que envolvem a sociedade moderna, torna praticamente impossível estabelecer uma base comum para regularização das questões problematizadas. Habermas aponta o direito como meio adequado para preencher esse déficit estabilizador social. Isso porque o direito moderno positivado se apresenta com a pretensão à fundamentação sistemática, à interpretação obrigatória e à imposição que institucionaliza (atribui validade) as pretensões de verdade (assertivas) que surgem na esfera pública -, com sua força impositiva que alcança todos, indistintamente, que estejam submetidos a sua ordem legal.

\section{ESTADO DE DIREITO: LÓGICA E INTERPRETAÇÃO}

Ao tratarmos das figuras do direito e do poder político, visualizamos uma interligação complexa que tende a preencher, reciprocamente, suas funções, sendo que, a partir da instrumentalização do direito, pode-se pensar uma elaboração estratégica do próprio poder do Estado. Uma anatomia da ideia do Estado de direito demanda, como veremos, uma compreensão do aparelho estatal descrito a partir de um sistema organizacional do direito, do qual, o uso autorizado do poder seja legitimado nos termos do direito legitimamente instituído. Com o sistema dos direitos, defini-se os pressupostos dos quais os membros de uma comunidade jurídica moderna recorrem, exclusivamente, para reclamar autenticidade quando do uso impróprio do poder. No Estado de direito, a comunidade moderna não apelará às ordens metafísicas ou religiosas e sim ao direito reconhecidamente positivado (SILVA, 2013, pg. 222).

No modelo discursivo, o direito governa e regulamenta os processos administrativos, concomitantemente ele representa o médium que transforma o poder comunicativo em poder administrativo. A partir do modelo discursivo, visualizamos 
algumas diferenças que devem ser consideradas do ponto de vista da legitimidade quando tratamos do direito, do conceito de dominação, do processo de normatização e da legitimação do exercício do poder político. Consoante análise, verifica-se que a socialização horizontal dos indivíduos espelha o conteúdo dos direitos fundamentais reconstruídos a partir de um experimento teórico; esses direitos são constitutivos para toda associação de membros jurídicos livres e iguais (SILVA, 2013, pg. 222).

No discurso filosófico da modernidade, Habermas (1990, pg. 276) aponta que tanto Hegel como Marx desconsideraram a ideia de se voltar a recuperar a intuição da totalidade ética para o horizonte da auto-referência do sujeito cognoscente e ativo, buscou-se, doravante, explicar segundo o modelo da formação natural da vontade situada numa comunidade que faz uso da comunicação - estabelecer obrigações em cooperações ${ }^{2}$. O processo de juridificação não deve estar limitado à esfera das liberdades subjetivas de ação das pessoas privadas e às liberdades de comunicação dos indivíduos, pois, se assim o fosse, comprometeria o entrelaçamento jurídico contínuo entre autonomia pública e privada. O processo de juridificação deve estender-se, simultaneamente, ao poder político - convalidado formalmente pelo médium do direito - do qual depende a obrigatoriedade fática da normatização e da implantação do direito.

\section{A relação interna entre direito e política}

O direito em sua função estabilizadora apresenta-se como um sistema de direitos. Dado esse pressuposto, entende-se que os direitos subjetivos só podem ser estatuídos e impostos a partir de organismos que tomam decisões de caráter obrigatório para toda coletividade. Com isso temos a figura dos direitos fundamentais que trazem em sua essência ameaças e sanções que podem ser usados contra interesses opostos ou transgressões de normas que surripiam o direito a iguais liberdades subjetivas. Esses

\footnotetext{
${ }^{2}$ Nessas passagens, o paradigma do conhecimento dos objetos deve ser substituído pelo paradigma da compreensão mútua entre sujeitos capazes de falar e de agir. Para Habermas, o paradigma da consciência encontra-se esgotado e, como tal, deve ser dissolvido para o paradigma da compreensão. Nesse sentido, já não se mostra mais privilegiada a atitude objetiva na qual o sujeito conhecedor se dirige a si próprio como a entidade no mundo (exterior). Vejamos que, numa interação mediada linguisticamente, os participantes assumem uma outra relação do sujeito consigo próprio, relação essa que se diferencia daquela atitude simplesmente objetiva que um observador assume com relação a entidades no mundo exterior.
} 
direitos pressupõem o poder de sanção de um órgão legalmente revestido, o qual dispõe de meios para o emprego legítimo da coerção para impor o acatamento, a submissão às normas jurídicas. O nexo interno do direito com o poder político reflete nas implicações objetivas e jurídicas estampadas na figura do Estado que mantém como reserva um poder militar, a fim de garantir seu poder de comando (HABERMAS, 2003, pg. 170). A pretensão a iguais direitos, numa comunidade de membro (livres) do direito, segundo Habermas, pressupõe uma coletividade limitada no espaço e no tempo, de forma que esses direitos asseguram a todos os membros dessa comunidade um reconhecimento recíproco, ou seja, eles se identificam como sujeitos de direitos, em outras palavras, há o reconhecimento dum status de direito conferido a todos em comum, de forma que eles podem imputar suas ações como partes do mesmo contexto de interações. Com suas palavras, Habermas (2001, pg. 153 - 154) se expressa na seguinte forma:

A reconstrução proposta da conexão entre os direitos de liberdade e os civis parte de uma situação na qual, como queremos admitir, cidadãos livres e iguais pensam em conjunto como podem regulamentar a sua vida em comum tanto por meio do direito positivo como também de modo legítimo (...). Esse modelo inicia-se com as relações horizontais dos cidadãos uns com os outros e introduz as relações dos cidadãos com o aparato estatal, necessários em termos funcionais, apenas em segundo passo, portanto já com base no direito fundamental já existente.

Essas considerações tangem sustentar a auto-afirmação sob a qual o Estado instaura sua capacidade para a organização e a auto-organização que buscar assegurar e manter - tanto no aspecto interno como no externo - a identidade da convivência juridicamente organizada.

O direito fundamental ratifica a cada cidadão o direito à proteção jurídica individual, de forma que as pretensões a uma justiça independente e imparcial nos julgamentos passam ser corolário do Estado de direito. O direito - como expressão da soberania estatal e tendo nesta seu único foco irradiador - resulta num instrumento de gestão da sociedade que busca dar segurança e garantia aos cidadãos. Com fundamento na soberania estatal é posto um conjunto de normas jurídicas que regulam a efetivação dos direitos e garantias. Esse conjunto é conservado, aplicado e, a todo momento, modifcado (POZZOLI, 2001, pg. 163). Assim, a instalação de um tribunal organizado politicamente assevera em cada julgamento o poder de sanção do Estado, pretendendo proteger e desenvolver o direito nos casos litigiosos, onde se faz mister uma decisão vol.08, nº. 01, Rio de Janeiro, 2015. pp. 350-385 355 
autoritária aplicada pelo Estado (juiz). A positivação política autônoma do direito, garantida a partir de um direito legitimamente instituído, concretiza-se em direitos fundamentais dos quais (surgem), asseguram condições para iguais pretensões à participação em processos legislativos democráticos, que demandam o exercício do poder político devidamente (legalmente) instituído. Além disso, o Estado, no seu exercício burocrático de dominação legal, faz valer concretamente a formação da vontade política que se organiza na forma do legislativo e, para tanto, conta diretamente com o poder executivo em condições de realizar e implementar os programas acordados. A presença do Estado no seu caráter de jurisdição - tanto administrativa como judicial - dependem da medida em que a sociedade se vale do médium do direito para influir conscientemente em seus processos de reprodução. Com isso, fala-se na dinâmica da auto-influência, acelerada por meio dos direitos de participação que fundamentam pretensões ao preenchimento dos pressupostos sociais, culturais e ecológicos úteis para o aproveitamento simétrico de direitos particulares de liberdade e de participação na vida política (SILVA, 2013, pg. 224). Em síntese, o Estado é necessário como poder de organização, de sanção e de execução, porque os direitos têm que ser implantados, porque a comunidade de direitos necessita de uma jurisdição organizada e de uma força para estabilizar a identidade, e porque a formação da vontade política cria programas que têm que ser implementados.

Tais aspectos não constituem meros complementos, funcionalmente necessários para o sistema de direitos, e sim, implicações jurídicas objetivas, contidas in nuce nos direitos subjetivos (HABERMAS, 2003, pg. 171). O poder organizado politicamente não se aproxima do direito como algo que lhe seja externo, pelo contrário, é pressuposto pelo direito; em outras palavras, o poder político organizado se estabelece em formas do direito. Nesse sentido, o poder político só pode desenvolver-se mediante a constituição de um código jurídico institucionalizado em conformidade com os direitos fundamentais. No Estado de direito, as decisões coletivamente obrigatórias são implantadas mediante o poder político organizado que o direito precisa tomar para a realização das suas funções próprias; não se revestem apenas a forma do direito, essas decisões devem - também - ser legitimadas pelo direito corretamente estatuído. As formações discursivas da opinião e da vontade figuram como premissas fundamentais para legitimidade do direito, ou seja, dentro do pensamento pós-tradicional, só vale 
como legítimo o direito que fora elaborado no interior de uma comunidade democrática que, utilizando do discurso racional, convenciona, normas reconhecidas reciprocamente pelos sujeitos. Consequentemente, institui-se a incorporação do exercício da autonomia política dos cidadãos em toda esfera do Estado - a legislação é reconhecida como um poder no Estado (SILVA, 2013, pg. 81). A transação dos direitos reciprocamente atribuídos na via da socialização horizontal pelos civis para formas verticais de organização socializadora faz com que a prática de auto-determinação dos civis seja institucionalizada - como formação informal da opinião na esfera pública política, como participação política no interior e no exterior dos partidos, como participação em votações gerais, na consulta e tomada de decisão de corporações parlamentares, etc (HABERMAS, 2003, pg. 17 - 173). Com efeito, a soberania popular interliga-se internamente com as liberdades subjetivas do civis, a mesma, por seu turno entrelaça-se com o poder politicamente organizado, de modo que o princípio "todo o poder político emana do povo", paulatinamente, concretiza-se por meio de procedimentos e pressupostos comunicativos de uma formação institucionalmente diferenciada da opinião e da vontade.

No Estado de direito delineado por regras da teoria do discurso, a soberania do povo não se encerra mais numa coletividade de cidadãos autônomos facilmente identificáveis. A soberania popular instala-se nos círculos de comunicação de foros e corporações destituídos de sujeitos determinados. Portanto, dado o anonimato, seu poder comunicativo diluído pode entrelaçar ao poder administrativo do aparelho estatal à vontade dos cidadãos. Nesse sentido, destaca Habermas (2003, pg. 173) que, no Estado de direito democrático, o poder político diferencia-se em poder comunicativo e administrativo. Tratando-se da correlação estante na vinculação interna entre política e direito, a tensão entre facticidade e validade, no Estado Democrático de Direito, estende-se ao âmbito do próprio poder político. A política com seu domínio, por um lado, vale-se da potencial ameaça fundada pela força da "caserna" e, por conseguinte, deve estar autorizada do ponto de vista do direito legítimo. Isso significa dizer que a dominação política deve espelhar a imagem do poder legitimado e organizado do ponto de vista jurídico, de modo que não se pode distanciar da perspectiva moderna, a qual entende que a legitimidade do poder, necessariamente, deve estar revestida pelo manto da legalidade. 
Entende-se que o exercício do poder na forma do direito não deve ser deslocado do momento de sua fundamentação. Essa preocupação consiste exatamente em reconstruir a constituição co-originária entre poder político e o direito, mostrando que, mediante essa relação, resulta um novo nível da tensão entre facticidade e validade, agora situada no próprio poder político, a questão da legitimação de um poder político estruturado na forma do Estado de direito pode ser compreendida desde que, por intermédio da ótica do conceito de autonomia política dos cidadãos. Para Aluisio Schumacher (2000, pg. 245), a contribuição do poder político para a função intrínseca do direito (estabilizar expectativas de comportamento) consiste na geração de uma certeza jurídica, que possibilita aos destinatários do direito calcular as consequências de seu comportamento e dos outros. As normas jurídicas, em termos gerais, devem regular as circunstâncias, as situações de fato, aplicando a sua subsunção de forma imparcial. Esses requisitos são compreendidos à luz de uma codificação (atividade jurisprudencial), que proporciona normas jurídicas altamente consistentes.

Com relação ao direito, sua contribuição à função intrínseca do poder administrativo (realizar fins coletivos) evidencia-se, especialmente, no desenvolvimento de normas secundárias, que, segundo Schumacher, não se tratam tão-somente daquelas normas que conferem poder (e até criam) às instituições governamentais dotando-as de jurisdições especiais, como também normas organizacionais que estabelecem procedimentos para a existência e gestão administrativa ou judicial de programas jurídicos. Assim, a atividade do direito, sua função e aplicabilidade, atinge outras esferas que não somente a da atividade jurisprudência jurídica, mas alcança também a esfera das instituições de governo - procedimentos e competências - garantindo, assim, a autonomia privada e pública dos cidadãos (SCHUMACHER, 2000, p.245).

\section{A LUTA POR RECONHECIMENTO NO ESTADO DEMOCRÁTICO DE DIREITO}

No Estado democrático de direito, o exercício do poder político regula-se a partir de duas codificações. Num primeiro momento, constata-se a necessidade de se entender como se dá o processamento institucionalizado dos problemas cogentes; num segundo instante, como se dá a mediação dos respectivos interesses, regrada segundo 
procedimentos claros, como efetivação de um sistema de direito. Depreende-se das constituições modernas uma ideia concebida sobre pressupostos do direito racional, do qual os cidadãos, por decisão própria, interligam-se a uma comunidade de jurisconsortes livres e iguais. Ora, a comunidade desses cidadãos, visando à estabilização das suas estruturas e as possíveis manutenções que se mostrarem necessárias, reclama uma constituição que assegure a todos eles um status que os iguale em direitos e garantias fundamentais. Esses direitos, garantidos pelas constituições, são identificados como direitos específicos dos quais os cidadãos, reciprocamente, reconhecem. Sendo assim, as constituições outorgarão a esses direitos - convencionados e instituídos a partir dos diálogos democráticos - o caráter de validade e, consequentemente, os convívios dos cidadãos, regulados pelo direito positivo, possuirão legitimidade conferida pela própria constituição. Nesse sentido, não obstante o direito moderno - via sanção estatal - reconheça e fundamente relações de reconhecimento intersubjetivo, esses direitos (prima facie) asseguram a integridade dos respectivos sujeitos em particular, potencialmente violáveis. "Em última instância, trata-se da defesa dessas pessoas individuais do direito, mesmo quando a integridade do indivíduo - seja no direito, seja na moral - dependa da estrutura intacta das relações de reconhecimento mútuo" (HABERMAS, 2007, pg. 237). O filósofo alemão faz uma releitura dos pressupostos de validade do direito, tomando como campo de pesquisa o mundo da vida onde ocorrem os discursos, os diálogos interpelativos, o próprio exercício democrático; entende o filósofo que, dado às novas complexidades que surgiram nesses espaços, o direito reclama outras leituras que considere também novas perspectivas e interesses outrora inexistentes:

Mas, nas arenas políticas, quem se defronta são agentes coletivos, que discutem sobre objetivos coletivos e acerca da distribuição dos bens coletivos. Apenas diante de um tribunal e no âmbito dum discurso jurídico é que se trata imediatamente de direitos individuais cobráveis por meio de ação judicial. Quanto ao direito vigente, também ele precisa ser interpretado de maneira diversa em face de novas necessidades e situações de interesse. Essa disputa acerca da interpretação e imposição de reivindicações historicamente irresolvidas é uma luta por direitos legítimos, nos quais estão implicados agentes coletivos que se defendem contra a desconsideração de sua dignidade. Nessa "luta por reconhecimento", segundo demonstrou A. 
Honneth, articulam-se experiências coletivas de integridade ferida (HABERMAS, 2007, pg. 238).

Assim, os discursos ocorridos nos espaços públicos democráticos podem conduzir à formulação de um sistema de direitos e de uma vontade política racional que se vincula a uma concepção de solidariedade cívica ou de patriotismo constitucional, que é necessário à implementação de instrumentos que tragam soluções aos emergentes conflitos decorrentes da convivência (interna e externa) nos contextos de diversidades culturais. Ao mesmo tempo, então, em que, os discursos proferidos nos espaços públicos destinados aos atos de fala constituem exercício efetivo da soberania popular, produzirão também concepções intersubjetivas de direitos fundamentais das quais se poderão pensar em condições e possibilidades de reconstruir a legitimidade dos Direitos Humanos com o objetivo de serem afirmados como direitos fundamentais universais (POKER, 2008, pg. 65). Vejamos que, em razão das conquista políticas liberais, bem como da social-democracia oriundas dos movimentos emancipatório e dos trabalhadores europeus, acreditou-se, então, numa teoria do direito que tornasse relevante algumas orientações de ordem individualistas. Essas ocorrências - lutas político-sociais de reconhecimento - objetivavam tão-somente suplantar a privação de direitos de grupos desprivilegiados e com isso, a fragmentação da sociedade em classes sociais; entretanto, as reivindicações daqueles grupos marginalizados que reclamavam para si chances iguais de vida no meio social, paulatinamente, ao se concretizar assumiram característica de universalização socioestatal dos direitos do cidadão. A filosofia de habermasiana aponta que, após a falência do socialismo de Estado, restou apenas essa perspectiva. $\mathrm{O}$ trabalho assalariado, a segurança, a justiça social e o bemestar figuraram, prima facie, expectativas de direitos que promoveriam, de forma fundamentada, a promoção do status social que seria alcançado com o acréscimo desses direitos legalmente compartilhados e com a participação na vida política (SILVA, 2014, pg. 233).

No denominado mundo pós-moderno, as comunicações e as decisões que são tomadas, sejam em nível nacional ou internacional, demarcam seções próprias de tempo e espaço. Assuntos de repercussão nacional ou internacional ligados aos direitos fundamentais e aos direitos humanos, e à escolha de temas e contribuições que são discutidas sob a pressão político-social consomem energias próprias, exigem um 
investimento particular em termos de organização, implicam, além disso, custos em termos de decisão protelada ou perdida. Afirma Pozzoli (2001, pg. 28) que:

Toda trajetória até então tida pela humanidade resultou em ter como princípio o respeito à vida, a continuidade da vida humana. Isto não pode ser negado. Assim, podemos ver o início de uma cultura indicadora do que hoje caracterizamos como dignidade da pessoa humana.

No que diz respeito às políticas de reivindicações, que buscam estabelecer igualdades de direitos, bem como o reconhecimento de identidades coletivas que visem a assegurar formas de vida culturais, por exemplo, feministas, minorias em sociedades multiculturais, povos que lutam por sua independência nacional ou regiões colonizadas no passado e que hoje reivindicam direitos e tratamentos igualitários. No cenário internacional, essas realidades dispares, diagnostificam uma realidade que parece contrariar a autocompreensão do Estado democrático de direito. Quando se discute políticas de reconhecimento de formas de vida e das tradições culturais sempre marginalizadas - ora no contexto de uma cultura majoritária, ora na sociedade mundial dominada por forças eurocêntricas ou do Atlântico Norte - necessariamente, não há que se falar também em garantias de status ou de sobrevivência? Com isso, não temos que apontar ao menos uma espécie de direitos coletivos dos quais faça romper a autocompreensão do Estado democrático de direito que herdamos moldada segundo direitos subjetivos, e, portanto de caráter liberal? (HABERMAS, 2007, pg. 239).

\section{Pretensões teóricas para o reconhecimento: o debate entre Taylor, Honneth e Habermas}

As considerações de Amy Gutmann, que nos é apresentada por Habermas, aponta que o reconhecimento público pleno conta com duas formas de respeito, a saber: 1) o respeito pela identidade individual de cada indivíduo, o que significa dizer que esse respeito independe de sexo, raça ou procedência étnica; e 2) o respeito pelas formas de ação, pelas práticas e visões peculiares de mundo que gozam de prestígio junto aos integrantes de grupos desprivilegiados ou que estão intimamente ligados a essas pessoas. Nessa perspectiva, as exigências que são colocadas, objetivamente, não visam a estabelecer, em primeira linha, um status que asseguraria um padrão isonômico de condições sociais de vida; antes, o que se busca, em primeira mão, seria a defesa da 
integridade de formas de vida e tradições com as quais os membros de grupos discriminados - de modo próprio - identificam-se. O não reconhecimento de grupos sociais soa como uma dissonância cultural segregativa que marginaliza alguns grupos previamente rotulados; origina-se e mantém-se tão-somente com as condições ingeridas de demérito social, de modo que, o não reconhecimento cultural e o demérito social se fortalecem de maneira cumulativa (SILVA, 2013, pg. 130).

Charles Taylor considera que, dado o fato de que o asseguramento de identidades coletivas possa concorrer com o direito a liberdades subjetivas iguais - com o direito humano único e original, na concepção kantiana -, o que configuraria uma área de colisão entre ambos, certamente, a partir do caso concreto, dever-se-ia decidir sobre a precedência de um ou outro. A reflexão que segue exposta depõe em favor disso:

Já que a exigência 2 exige a consideração de particularidades das quais a exigência 1 parece abstrair, o princípio de tratamento equitativo deve alcançar validação nas políticas concorrentes - em uma política de respeito por todas as diferenças, por um lado, e em uma política de universalização de direitos subjetivos, por outro. Uma política deve compensar as desvantagens do universalismo uniformizante que a outra ocasiona (HABERMAS, 2007, pg. $240-241$ ).

Em seu ensaio seminal sobre o multiculturalismo, Taylor (1994, pg. 26) entende que o reconhecimento não se trata de algo oriundo de uma cortesia, antes de tudo, trata-se da necessidade humana. Portanto, isso significa dizer que, pessoas e grupos podem - de certa forma - sofrerem danos consideráveis se a sociedade os identifica com imagens restritivas e depreciativas. Por meio das interações intersubjetivas (sejam elas agonísticas ou amistosas) e dialogais os sujeitos passam ser reconhecidos como tais, destarte, eles podem realizar suas originalidades insitas. A propósito, em um mundo que construiu uma imagem individualizada de identidade, consubstanciada pelo princípio de autonomia, uma vez que eu não sou verdadeiro comigo mesmo, consequentemente, eu passo a desconhecer a própria essência da minha identidade (da minha vida); consequentemente, eu passo a ignorar o que o ser humano significa para mim (TAYLOR, 1994, pg. 30). Essa autonomia só pode ser construída em diálogos em parte, externos e, em parte, internos - com os outros.

Taylor busca fundamentar seus argumentos teóricos sobre bases históricofilosóficas, e assim, retoma os alicerces valorativos que delineiam e estruturam a própria 
existência da sociedade. Desse modo, não seria absurdo pensar, por exemplo, que existem hierarquias valorativas tácitas que transcendem práticas cotidianas e instituições que se apresentam como imparciais, ou neutras, tais como o mercado e o Estado. Ora, vejamos que, a própria configuração dos sujeitos, atrelada às práxis do cotidiano, é regulada por princípios morais, ao que Taylor (1997, pg. 35) denomina configurações. Uma "configuração incorpora um conjunto crucial de distinções qualitativas. Pensar, sentir, julgar no âmbito de tal configuração é funcionar com a sensação de que alguma ação ou modo de vida ou modo de sentir é incomparavelmente superior aos outros". Para Souza, Taylor está interessado, antes de tudo, "no componente avaliativo da constituição da identidade humana, na medida em que a auto-interpretação dos sujeitos passa a ser percebida como momento constitutivo para a construção desta" (SOUZA, 200oa, pg. 99).

Em uma espécie de arqueologia ligada à concepção de bem, Taylor pretende encontrar a autocompreensão dos atores com vistas a definição moral da época considerando essencialmente a cultura em que esses atores estão inseridos, o substrato das suas identidades (SOUZA, 200ob, pg. 137). Nessa perspectiva, na contemporaneidade, talvez o mais urgente e poderoso conjunto de exigências que reconhecemos como morais aponta o respeito à vida, à integridade, o bem-estar e mesmo à prosperidade dos outros. Desse modo, a figura da dignidade passa ser compreendida como a sendo a essência mátria do pano de fundo moral que rege as sociedades ocidentais contemporânea, superestimando a capacidade destas de implementar uma universalização de direitos que naturalize o valor da igualdade (MATTOS, 2004, pg. 157). Para o filósofo canadense, na modernidade, houve um declínio da sociedade hierarquicamente predeterminada, o que comprometeu significativamente a honra estamental em direção à dignidade geral. Enquanto a política da dignidade universal rechaçava as formas de discriminação, que eram bastante "cegas" com relação aos modos em que os cidadãos se diferem, a política da diferença, frequentemente, redefine a não-discriminação pretendendo como isso ver nas distinções a base do tratamento diferencial. Para Taylor (1994, pg. 39), a busca pelo reconhecimento envolve esses dois tipos de política, buscando no horizonte da consciência da igualdade do valor humano a valorização daquilo que cada um fez a partir dessa igualdade. 
Para Habermas, tanto Taylor quanto Walzer contestam a ideia de uma suposta neutralidade ética no direito, resultando daí uma expectativa formada sobre os preceitos do Estado de direito que tem como ideal a fomentação ativa de determinadas concepções do bem viver, caso isso se faça necessário. A partir das suas considerações, Taylor sugere um modelo alternativo que, de acordo com determinadas condições, é possível se pensar em garantias de status restritivas aos direitos fundamentais, desde que essas garantias possam assegurar a sobrevivência de formas de vida cultural, e que assegurem também o exercício de políticas ativamente empenhadas em gerar novos integrantes desses grupos, desde que dedicadas, por exemplo, a que as futuras gerações possam também identificar-se com seus precedentes. Nesse sentido, as compreensões de ordem política que envolvem deliberações, exercício e garantias de direitos fundamentais não estarão preocupadas tão-somente com os direitos inerentes às populações já existentes; antes, as reivindicações alcançarão os direitos das populações futuras (SILVA, 2013, pg. 133). Assim, por meio de lutas simbólicas, os sujeitos negociam identidades, buscam reconhecimento próprio e social. Essas lutas, cada vez mais explícitas, transcendem interesses particulares, seus efeitos, tomam proporções gigantescas por via de protestos públicos que não buscam a simples tolerância ou condescendência, mas o respeito e a valorização do diferente.

Em primeiro lugar, é preciso observar - conforme aponta Habermas - que Taylor torna plausível sua tese da inconciliabilidade ao apresentar sua teoria dos direitos sob um enfoque seletivo de leitura ligado ao liberalismo. A teoria tayloriana, portanto, estabelece seu fundamento sobre o pressuposto de um status equitativo de liberdades de ação subjetivas, em forma de direitos fundamentais, para todos os jurisconsortes. $\mathrm{Na}$ hipótese da existência de casos controversos, o tribunal decidirá quais direitos cabem e a quem; assim, o princípio da equidade de direitos para todos "encontra validação tãosomente sob a forma de uma autonomia juridicamente apoiada, à disposição do uso de qualquer um que pretenda realizar seu projeto de vida pessoal" (HABERMAS, 2007, pg. 242). Essa interpretação atribuída ao sistema de direito é fortemente criticada por Habermas, que a caracteriza como sendo:

Paternalista, porque corta pela metade o conceito de autonomia. Ela não leva em consideração que os destinatários do direito só podem ganhar autonomia (em sentido kantiano) à medida que eles mesmos possam 
compreender-se como autores das leis às quais eles mesmos estão submetidos como sujeitos privados do direito. O liberalismo 1 ignora a equiprocedência das autonomias privada e pública. Não se trata aí apenas de uma complementação que permaneça externa à autonomia privada, mas sim de uma concatenação interna, ou seja, conceitualmente necessária (HABERMAS, 2007, pg. 242).

Habermas (2007, pg. 243) entende que, enquanto aos sujeitos não estiverem assegurado o exercício comum e conjunto da sua autonomia enquanto cidadãos do Estado, consequentemente, o desfrute das liberdades subjetivas comuns estará embaraçado, ou seja, impedido. A orientação proposta pelo filósofo alemão vem fundamentada sobre a ideia impreterível de se estabelecer uma concatenação interna entre o Estado de Direito e a Democracia; consequentemente, teremos um sistema de direito que alcançará todos os modos de vida presentes no Estado, desde aquelas vidas circunscritas no centro urbano como aquelas postas à sua margem. Sendo assim, o sistema de direito poderá ouvir as múltiplas diferenças culturais existentes e, como tal, deverá assisti-las em suas diferenças devendo prestar-lhes respostas quando por elas for invocado.

Em suas considerações Honneth aponta que por meio do reconhecimento intersubjetivo os sujeitos podem garantir realização plena das suas capacidades, bem como chegar a uma auto-relação marcada pela integridade, ou seja, os sujeitos, dadas suas interações, recebem certa modulações, destarte, só conseguirão formar uma autorelação positiva caso possam se sentir reconhecidos por seus parceiros de interação.

A teoria de Honneth (2003, pg. 152) observa também substrato normativo presente nas relações sociais. Sua teoria parte do princípio de que o conflito é intrínseco, portanto necessário, tanto à formação da intersubjetividade como dos próprios sujeitos. Desse modo, conflito não é tomado apenas pela lógica da autoconservação dos indivíduos, como descrito no estado de natureza de Hobbes. Seu significado tem por preceito a conotação de uma luta moral, entendendo que a organização da sociedade, necessariamente, deve estar pautada por obrigações intersubjetivas. Honneth concatenua a idéia hegeliana com a psicologia social de George H. Mead.

Mead (1993, pg. 97) direciona suas pretensões teóricas a partir de um horizonte intersubjetivista, defendendo a existência de um diálogo interno que toma os impulsos 
individuais e a cultura internalizada como objeto de pesquisa, e investiga a importância das normas morais nas relações humanas. Mead situa as interações sociais como campo onde ocorrem os conflitos entre o eu, a cultura e os outros. O teórico norte-americano defende a gênese social da identidade e vê a evolução moral da sociedade sempre atrelada à luta por reconhecimento forjada a partir de três tipos de relação: as primárias (reguladas pelo amor), as jurídicas (reconhecidas pela lei) e a esfera do trabalho onde está presente o valor do indivíduo com relação a coletividade.

A partir dessas premissas, Honneth (2003, pg. 156) sistematiza uma teoria do reconhecimento, descrevendo que são as lutas moralmente motivadas de grupos sociais, sua tentativa coletiva de estabelecer institucional e culturalmente formas ampliadas de reconhecimento recíproco, aquilo por meio do qual vem a se realizar a transformação normativamente gerida das sociedades. Hannet entende que o descaso, o desprezo social e político podem tornar impulsos que dinamizam lutas sociais, à medida que torna evidente que outros atores impedem a realização daquilo que se entende por bem viver, ou seja, se por um lado, o rebaixamento e a humilhação ameaçam identidades, por outro, eles estão na própria base da constituição de lutas por reconhecimento. Portanto, isso significa dizer, que toda reação emocional negativa que vai de par com a experiência de um desrespeito de pretensões de reconhecimento contém novamente em si a possibilidade de que a injustiça infligida ao sujeito se the revele em termos cognitivos e se torne o motivo da resistência política (HONNETH, 2003, pg. 224).

Na concepção de Habermas, essa premissa constitui-se como condição vital sinequa non para que uma teoria dos direitos, entendida de maneira correta, venha a exigir, exatamente, e assegurar o direito ao exercício da política de reconhecimento que preserva a individualidade e a integridade do indivíduo até nos contextos vitais que conformam sua identidade ou a configuram. Nesse sentido, não é preciso que se formule um modelo oposto que corrija o viés individualista do sistema de direitos sob outros pontos de vista normativos; é preciso apenas que ocorra a realização coerente desse viés. Entende Habermas que os movimentos sociais e as lutas políticas são extremamente relevantes para concretização do reconhecimento. $\mathrm{O}$ autor compreende ser necessário que se crie e disponibilize competências jurídicas iguais das quais surgem espaços para liberdades de ação que podem ser utilizadas diferenciadamente, ou seja, não se fomenta a ideia de um formalismo irrestrito com vistas a uma igualdade factual 
de situações de vida ou de poder; antes, o multiculturalismo é visto de forma salutar para a manutenção das identidades coletivas, seja no contexto de uma cultura majoritária ou em meio à comunidade dos povos. Contudo, observa o filósofo que alguns pressupostos factuais devem ser cumpridos para que "competências jurídicas sob condições de igualdade sejam distribuídas com equidade, caso se deseje evitar que o sentido normativo da igualdade de direitos se inverta por completo" (SILVA, 2013, pg. 83).

Essa preocupação consiste exatamente em reconstruir a constituição cooriginária entre poder político e o direito, mostrando que, mediante essa relação, resulta um novo nível da tensão entre facticidade e validade, agora situada no próprio poder político. Nesse sentido, a questão da legitimação de um poder político estruturado na forma do Estado de direito pode ser compreendida desde que, por intermédio da ótica do conceito de autonomia política dos cidadãos, fundamentado na teoria do discurso, se consiga diferenciar as figuras do poder comunicativo, produto do direito legítimo, e a do poder administrativo, responsável por imposições das leis (WERLE, 2008, pg. 130 - 131). Assim, a contribuição do poder político para a função intrínseca do direito (estabilizar expectativas de comportamento) consiste na geração de uma certeza jurídica, que possibilita aos destinatários do direito calcular as consequências de seu comportamento e dos outros. As normas jurídicas, em termos gerais, devem regular as circunstâncias, as situações de fato, aplicando a sua subsunção de forma imparcial. Esses requisitos são compreendidos à luz de uma codificação (atividade jurisprudencial), que proporciona normas jurídicas altamente consistentes.

Com relação ao direito, sua contribuição à função intrínseca do poder administrativo (realizar fins coletivos) evidencia-se, especialmente, no desenvolvimento de normas secundárias, que, segundo Schumacher, não se tratam tão-somente daquelas normas "que conferem poder (e até criam) às instituições governamentais dotando-as de jurisdições especiais, como também normas organizacionais que estabelecem procedimentos para a existência e gestão administrativa ou judicial de programas jurídicos". Assim, a atividade do direito, sua função e aplicabilidade, atinge outras esferas que não somente a da atividade jurisprudência jurídica, mas alcança também a esfera das instituições de governo - procedimentos e competências - garantindo, assim, a autonomia privada e pública dos cidadãos (SCHUMACHER, 200o, pg. 246). 
Numa releitura dos séculos XX e XIX, depreende-se que alguns agentes sociais sobretudo o feminismo, sob fortes oposições, precisaram empreender várias investidas para fazer valer seus objetivos legais e políticos. Inicialmente, a política liberal tencionou desacoplar conquistas de status e identidade de gênero, com seus reclames e protestos - conteúdo de seus ideários: as mulheres passaram a obter igualdades de chances na concorrência por postos de trabalho, prestígio social, nível de educação formal, poder político, etc. A igualdade formal que fora alcançada parcialmente pode agregar tão-somente uma fração da sociedade; com isso, evidenciou-se, ainda mais, as desigualdades de tratamento factual a que as mulheres estavam submetidas. Nesse contexto, políticas socioestatais, voltadas à implementação dos direitos (reconhecimentos) sociais ligados ao trabalho e a família, reagiram com regulamentações especiais; por exemplo, a maternidade e os encargos sociais, em caso de divórcio. Entrementes, a crítica feminista indignou-se contra as exigências liberais não resolvidas bem como contra os programas sociais implementados com êxito que trouxeram consequências ambivalentes, como os riscos de acidentes e infecções patológicas nos ambientes de trabalho, a presença excessiva de mulheres nos cargos de baixíssima remuneração laborativa, o bem-estar infanto-juvenil evidentemente problematizado, a crescente "feminização" da pobreza de modo geral, etc (HABERMAS, 2007, pg. 244). Habermas aponta, ainda, um fator preponderante que corroborou diretamente para a implementação dos estereótipos de identidades de gênero: em áreas do direito feminista, o paternalismo socioestatal assume um sentido literal e, nesse sentido, tanto o poder legislativo e a própria jurisdição passam orientar-se conforme os modelos tradicionais de interpretação que existiam. A classificação dos papéis sexuais e das diferenças do gênero compõem as camadas elementares da autocompreensão cultural da sociedade, com isso, considera Habermas que :

Só agora o feminismo radical toma consciência do caráter dessa autocompreensão, que se revela falível, profundamente questionável e carente de revisão. Ele insiste, e com razão, em que se devem esclarecer junto à opinião pública de caráter político, ou seja, em um debate público acerca da interpretação adequada das carências, os enfoques sob os quais as diferenças entre experiências e situações de vida de determinados grupos de homens e mulheres se tornam significativos para um uso das liberdades de ação em igualdades de chances (HABERMAS, 2007, pg. 245). 
A partir dessas considerações, Habermas acredita ser possível demonstrar, de forma clara, a transformação da compreensão paradigmática do direito que se configura ora pelas liberdades subjetivas em prol das concorrências em particular, ora mediante reivindicações de benefícios, ideário do Estado de bem-estar social. Com isso, obtemos uma concepção procedimental do direito, em que o processo democrático, a um só tempo, pode assegurar a autonomia privada e pública. Devemos considerar - a partir dos debates públicos - os aspectos relevantes para o tratamento igualitário ou desigual de casos típicos isolados, caso se queira assegurar às mulheres uma organização particular e autônoma da própria vida condizente com seus direitos subjetivos. As perspectivas fomentadas pelas lentes liberais do sistema de direitos que não considera essas relações, evidentemente, não se manterão; a não ser no entendimento errôneo do universalismo dos direitos fundamentais como nivelamento abstrato de diferenças tanto culturais como sociais. Vejamos que o sistema do direito, caso se queira tornar efetivo por via democrática, deverá considerar, de forma séria, as diferenças sociais e culturais relevantes em cada contexto (HABERMAS, 2007, pg. 245).

\section{BIOPOLÍTICA, CIDADANIA E RECONHECIMENTO}

Os fenômenos sociais que potencializam os sujeitos, as comunidades e as nações a lutarem por um reconhecimento, muito embora, na maioria dos casos, sejam homogêneos e ainda demonstrem características similares, como é o caso do feminismo, o multiculturalismo, o nacionalismo e a luta contra a herança eurocêntrica do colonialismo, ainda que possam demonstrar algumas semelhanças, não podem ser confundidos, dado o fato das peculiaridades essenciais. Vejamos que a semelhança nos parece evidente, pois tanto as mulheres, as minorias étnicas e culturais, assim como também, as nações e culturas, todas se defendem da opressão que é lançada, da marginalização e do desprezo nos quais são encerrados. A defesa desses atores sociais se constrói mediante lutas e manifestos incessantes de reconhecimento de identidades coletivas, seja no contexto de uma cultura majoritária, seja em meio à comunidade dos povos. Esses aguerridos manifestos sociais são movimentos que buscam sua emancipação própria voltada sempre aos seus ideários políticos coletivos definidos culturalmente (SILVA, 2013, pg. 89). Destarte, a questão do reconhecimento não afeta 
tão-somente questões de ordem diretamente ligadas à dignidade humana, mas também considerações de ordem jurídica que comprometem diretamente carências da vida humana. Em suas palavras, Habermas (2000, pg. 246) aponta que:

Embora o feminismo não seja a causa de uma minoria, ele se volta contra uma cultura dominante que interpreta a relação dos gêneros de uma maneira assimétrica e desfavorável à igualdade de direitos. A diferença de situações de vida e experiências peculiares ao gênero não recebe consideração adequada, nem jurídica nem informalmente; tanto a autocompreensão cultural das mulheres quanto a contribuição que elas deram à cultura comum estão igualmente distantes de contar com o devido reconhecimento; e, com as definições vigentes, as carências femininas mal podem ser articuladas de forma satisfatória.

A luta política por reconhecimento centra-se em discursos debatidos nos espaços públicos voltados à interpretação de interesses de realizações peculiares aos diferentes gêneros; à medida que logra êxito, essa luta modifica a identidade coletiva das mulheres e, por conseguinte, acarreta, também, algumas mudanças de relações entre os gêneros, afetando, assim, de forma imediata, a autocompreensão dos homens. Com isso, aqueles valores reconhecidos em escala na sociedade são levados para os debates discursais, de forma que, dado o caráter de relevância desses valores para sociedade, a consequência da problematização desses valores chega até as áreas centrais da vida privada e, portanto, afetam os limites estabelecidos entre as esferas pública e privada, a situação se difere quando se trata da luta das minorias étnicas e culturais pelo reconhecimento de sua identidade coletiva; já que esses movimentos de emancipação visam, também, à superação da divisão (ou separação) ilegítima da sociedade, a autocompreensão da cultura majoritária pode não sair ilesa (SILVA, 2013, pg. 90). Nas sociedades multiculturais os movimentos de emancipação não representam, resumidamente, fenômenos unitários. Isso significa dizer que eles se diferenciam de acordo com as diversas situações; por exemplo, as minorias endógenas - considera o autor - podem tornar-se conscientes de sua identidade ou, por conta da imigração, poderão surgir novas minorias, e, mesmo assim, esse fenômeno ocorrerá com as políticas culturais de alguns Estados que se autocompreendem como Estados de migração, cabendo, essa tarefa de emancipação também aos Estados, cuja autocompreensão nacional dependa de uma adaptação à integração de culturas estrangeiras (HABERMAS, 2007, pg. 247). 
Outra distinção abordada na filosofia habermasiana diz respeito novo tipo de nacionalismo que trata daquelas populações que compartilham entre si um destino histórico comum. Essas populações identificam e organizam-se em grupos étnicos linguisticamente homogêneos e, como tal, desejam manter sua identidade não apenas como comunidades ascendentes comuns, mas também sob a forma de um povo que se organiza como Estado, possui autonomia política. O modelo de movimentos nacionais, considerado por Habermas (2000, pg. 246):

Quase sempre foi o Estado nacional constituído por via republicana, tal como surgiu da Revolução Francesa. A Itália e a Alemanha, em comparação com os Estados nacionais da primeira geração, foram chamadas "nações tardias". Outro contexto foi dado pelo período de descolonização após a Segunda Guerra Mundial. Outra constelação, por sua vez, é dada pela decadência de impérios como o Reino Otomano, a Áustria-Hungria ou a União Soviética.

Disso se distinguem algumas situações de minorias nacionais que surgiram em virtude da formação de Estados nacionais, por exemplo, os bascos, curdos e irlandeses do norte. Um caso especial identificado por Habermas é a fundação do Estado de Israel, sua instituição fôra em decorrência de movimentos nacional-religiosos e dos horrores humanos ocorridos em Auschwitz, na região da Palestina, inicialmente de mandato inglês e reivindicado por árabes (HABERMAS, 2007, pg. 248).

Em nível internacional, a luta por reconhecimento surgiu em decorrência do eurocentrismo e do predomínio da cultura ocidental no campo político mundial, ambos vistos por Habermas (2007, pg. 249) como condições essenciais para uma luta por reconhecimento em nível internacional. O filósofo aponta a Guerra do Golfo como um fato que tornou consciente essa dimensão. A percepção daquilo que ocorrera, os motivos políticos, os interesses camuflados, se deram às "sombras de uma história colonial ainda presente, a intervenção dos aliados foi vista por massas religiosamente mobilizadas e também por intelectuais secularizados como abuso da identidade e autonomia do mundo arábico-islâmico". Os vestígios, as marcas indeléveis dessas lutas fracassadas de reconhecimento marcam, até hoje, as relações históricas (a economia, a política, a religião, as relações de direitos humanos, etc.) entre Ocidente e Oriente e, tanto mais, o relacionamento do Primeiro Mundo com o Terceiro, como antes era chamado. 
No debate sobre political correctness, fenômeno que ocasionou, em primeiro lugar, um autoentendimento entre os intelectuais norte-americanos sobre o status da modernidade, o que, para os radicais, significa um avanço entusiasta rumo à pósmodernidade e à remoção de figuras de pensamento totalizadoras, para os tradicionais seria o sinal de uma crise que só poderá ser superada por um persistente regresso às tradições clássicas do ocidente. Num outro plano mais elaborado, situam-se os discursos filosóficos em sentido estrito, que consideram, de sobremodo, os problemas já referidos e os toma como ponto de partida para descrever os problemas de ordem geral. Esses fenômenos prestam-se aos esclarecimentos e às considerações explícitas quanto à dificuldade do acordo mútuo intercultural; eles esclarecem a relação entre moral e eticidade, ou uma interligação entre significação e validação, e reacendem a velha questão sobre podermos transcender o contexto de nossa respectiva língua e cultura ou, ao contrário, todos os padrões de racionalidade estarão atrelados a determinadas imagens de mundo e determinadas tradições (SILVA, 2013, pg. 97). Com suas palavras, Habermas (2007, pg. 250) aponta que:

As esmagadoras evidências da fragmentação de sociedades multiculturais e da confusão linguística babilônica em meio a uma sociedade mundial mais que complexa parecem compelir-nos a concepção holística de linguagem e a concepção contextualísticas de imagens de mundo que soam céticas em face de tantas reivindicações universalistas, sejam elas de natureza cognitiva ou normativa.

O autor ainda nos mostra que o debate sobre a realidade, ramificado e aberto até há pouco tempo, é de vital importância tendo em vista que seus resultados trazem consequências que tocam diretamente as considerações apresentadas em torno dos conceitos de bom e justo com os quais lidamos ao investigar as condições de uma política do reconhecimento. Nesse sentido, uma sugestão apontada por Taylor, em si mesma, remete-se a outra coisa; ela está embasada - considera Habermas - no plano de referências do direito e da política.

Nesse sentido, o problema do direito ou direitos de minorias ofendidas e maltratadas passa a ser um problema de ordem jurídica e, como tal, deve ser resolvido. No Estado de direito, decisões políticas não podem infringir normas do direito positivo, ou seja, as decisões políticas, para que sejam validas, deverão se servir das vol.08, nº. 01, Rio de Janeiro, 2015. pp. 350-385 372 
regulamentações do direito positivo para tornarem-se efetivas em sociedades complexas. Dessarte, o médium do direito aponta para uma estrutura artificial onde decisões normativas prévias se relacionam. Verificamos, portanto, que o direito moderno em sua estrutura é identificado como formal e se embasa na premissa de que tudo não seja explicitamente proibido e permitido. $\mathrm{O}$ direito moderno reconhece, individualmente, cada pessoa como sujeito portador de direitos subjetivos; nesse sentido, como titulares de uma categoria de direitos, esses mesmos sujeitos podem valendo-se desses direitos - tutelar judicialmente, contra particulares ou até mesmo contra o Estado, direitos que lhes subtraíram. Nas palavras de Habermas (2007, pg. 250), o direito moderno é identificado como:

Um direito coercivo porque sanciona de maneira estatal e estende-se apenas ao comportamento legal ou conforme normas - ele pode, por exemplo, tornar livres as religiões, mas não pode prescrever nenhuma consciência moral. É um direito positivo porque retroage às decisões modificáveis - de um legislador político, e é, finalmente, um direito escrito por via procedimental, já que legitimado mediante um procedimento democrático.

O direito moderno - positivo - muito embora regule comportamentos legais, ainda assim, para sua validade, deve ser reconhecido como legítimo. Não obstante seu reconhecimento, respeito e obediência por todos, o direito moderno deve ser reconhecido de maneira que também possa ser cumprido a qualquer momento por seus destinatários, pelo simples respeito à lei. Para Habermas, uma ordem jurídica é definida como legítima quando assegura, de forma equitativa, a autonomia de todos os cidadãos. Esta autonomia estará concretamente constituída no instante em que destinatários do direito entenderem-se como seus autores e destinatários. Tais autores então, como participantes do processo legislativo, serão livres tão-somente se esse processo estiver regrado por atos de fala discursivos e, necessariamente, democráticos, em que todos possam supor que as regras ora firmadas e, desse modo, mereçam concordância geral sancionada pela razão. Por entendimento, faz-se menção a um processo discursivo racional que leva os sujeitos ao convencimento objetivado entre as partes. Esse processo coordena as ações de fala de todos os participantes por meio da razão que vale como motivação e regularização, sendo que as ações de fala são utilizadas como meio para se chegar ao convencimento e, por conseguinte, ao consenso. Desse modo, entendimento 
é o "processo de obtenção de um acordo entre sujeitos linguística e inteiramente competentes" (HABERMAS, 1987a, pg. 368).

A partir dessa formulação, o conceito tradicional de razão prática adquire um valor heurístico: ele se torna fio condutor para reconstrução do emaranhado dos discursos; consequentemente, a concepção normativa que interpreta o direito, mormente filiado à moral passa a ser recusado na filosofia habermasiana. O processo democrático deve ser institucionalizado juridicamente, o princípio da soberania dos povos exige, o devido respeito a direitos fundamentais sem os quais, simplesmente, não pode haver um direito legítimo. Nesse sentido, Habermas (2007, pg. 251) fala, em primeira linha, do direito à liberdades de ações subjetivas iguais que, por sua vez, pressupõem defesas jurídicas individuais e abrangentes. Com a instituição do Estado de direito e o reconhecimento dos direitos subjetivos dos indivíduos, há consequências salutares para o tratamento do problema da isonomia jurídica e do igual reconhecimento de grupos culturalmente definidos, ou seja, de coletividades que se distinguem de outras - seja pela tradição, forma de vida, proveniência étnica, etc.

\section{Soberania popular: deliberações, assentimentos, processos cognitivos e legitimidade procedimental}

Em primeiro lugar, Habermas (2003, pg. 162) considera que só podem ser tomados por legítimos os processos nos quais os sujeitos, livremente, se reúnem em torno de algo para deliberarem. Isso significa dizer que os participantes não serão conduzidos por algo externo ao seu intento, enquanto agentes de atos de fala discursiva racionalmente fundamentada, todavia isso não exclui a possibilidade do falibilismo, pois a busca pela resposta unívoca não garante, por si mesma, um resultado correto. Para o filósofo "somente o caráter discursivo do processo de deliberação é capaz de fundamentar a possibilidade de autocorreções reiteradas e, destarte, a perspectiva de resultados racionalmente aceitáveis". Em segundo lugar, os participantes devem comprometer-se, por meio de um questionamento específico, e tomar o direito moderno como médium para regular suas convivências. Da legitimação empregada ao consentimento geral obtido sob condições do discurso democrático, vinculado às leis obrigatórias que abrem espaços para iguais liberdades subjetivas, remonta ao conceito 
kantiano da ideia de autonomia política: "aqui ninguém é livre, enquanto houver um único cidadão impedido de gozar da igual liberdade sob leis que todos os cidadãos se deram a si mesmos, seguindo uma deliberação racional”.

Para uma compreensão válida sobre o sistema dos direitos fundamentais, cumpre analisarmos, de antemão, algumas objeções quanto à tentativa procedimentalista de combinar a ideia dos direitos humanos com o princípio da soberania do povo. Dada a relevância dessas objeções, mister se faz obter clareza sobre as consequências da proposta que busca explicar a forma do Estado de direito democrático sob o viés da institucionalização jurídica de uma ampla rede de discursos. Por uma questão lógica, os discursos públicos passam a ser especificados em detrimento do objeto no qual são formulados e, sendo assim, há que se considerar, também, o tempo e o contexto social, tendo em vista a formação política da opinião e da vontade em espaços públicos e nas corporações legislativas, bem como nos atos jurídicos e administrativos decisórios. Ainda nas considerações observadas por Habermas, a visão de Michelman dirigi-se para esta dimensão da regulação jurídica; por conseguinte, abrange tanto os direitos fundamentais e políticos, passando pelas determinações da parte organizacional da constituição, alcançando os direitos procedimentais e as ordens do dia de corporações. Vê Habermas (2003, pg. 165 - 166) que, Michelman aponta para a dimensão do estabelecimento de formas de comunicação, sabendo que a prática constituinte não pode ser reconstruída conforme critérios da teoria do discurso, pois, certamente, chegar-se-ia a um processo circular infindável. Ora, um processo democrático confiável é, necessariamente, um processo continuado e condicionado legalmente por leis que buscam uma representação política por associações civis e familiares, o direito à liberdade de fala, à propriedade, o acesso à mídia. Dessarte, as leis que tratam desses objetos devem ser constituídas por meio de procedimentos válidos, politicamente democráticos, sem distorções, não somente nos ambientes estatais, mas, também, nas redes da sociedade como um todo.

Graças a esse sentido performativo disponível para cada cidadão ligado a uma comunidade política democrática, cada um pode contribuir, à sua maneira, para explicar o que significa perseguir e concretizar o projeto de uma associação de sujeitos livres e iguais que se autodeterminam. Destarte, qualquer ato fundador abre possibilidades a um processo ulterior que se autocorrige reestruturando as fontes do vol.08, nº. 01, Rio de Janeiro, 2015. pp. 350-385 375 
sistema de direito. A interpretação discursiva da autoconstituição democrática do Estado constitucional exige ainda, que demonstremos como os princípios democráticos são inerentes à constituição da democracia enquanto tal. Devemos explicar em que sentido os direitos fundamentais, em sua totalidade, são constitutivos para o processo da autolegislação, o que suplantaria a suposta objeção paradoxal estante entre democracia e Estado de direito.

Num primeiro momento, os participantes compreendem que, para realizar seu projeto pelo caminho do direito, há que se criar uma ordem de status, de forma que todo e qualquer cidadão e, até mesmo aqueles que irão engajar-se futuramente ao projeto, serão reconhecidos como portadores de direitos subjetivos. Tal ordem de direito positivo e obrigatório com traços subjetivistas, será concretizada desde que sejam introduzidos os direitos fundamentais de conteúdo concreto variável, (I) que resultam da configuração autônoma do direito e que asseguram as liberdades subjetivas para cada um, (II) que resultam da configuração autônoma do status de membro de uma associação livre de parceiros do direito, (III) que resultam da configuração autônoma do igual direito de proteção individual. Nesse sentido, reflete Habermas que essas três modalidades de direito são fundamentais para a constituição de uma associação de parceiros jurídicos que se reconhecem, reciprocamente, como portadores de direitos subjetivos reclamáveis. Por conseguinte, para sua instituição, ainda se faz necessário que se introduza uma nova categoria de direitos fundamentais: direitos fundamentais (de conteúdo concreto variável) que resultam da configuração autônoma do direito, visando a assegurar uma participação em igualdade de condições na esfera da legislação política (HABERMAS, 2003, pg. 168 - 169). Assim, o princípio democrático somente pode ser concretizado no mundo dos fatos desde que haja, efetivamente, o Estado de direito, pois ambos os princípios se locupletam reciprocamente numa relação de implicações materiais congênitas.

\section{AUTONOMIA POLÍticA, RAZÃO DISCURSIVA E SOBERANIA POPULAR}

A tensão existente entre a soberania popular e os direitos humanos não pode ser solucionada - segundo o pensamento de Habermas (2001, pg. 146 - 147) - de modo sério, 
com base na teoria política, ou seja, a teoria política está aquém das condições necessárias para equacionar essa tensão. O republicanismo, que remonta a Aristóteles e ao Humanismo político do Renascimento, sempre concedeu preferência à autonomia pública dos cidadãos em detrimento das liberdades não-políticas dos indivíduos privados. O liberalismo que se refere a Locke denunciou o perigo suscitado pelos atos da maioria tirânica e postulou a precedência dos direitos humanos com relação à vontade do povo. Desse modo, não há alarde algum quanto ao motivo pela qual as teorias do direito tenham dado uma dupla resposta às questões de legitimação, ou seja, por um lado faz-se referência ao princípio da soberania popular e, por outro, faz-se alusão ao domínio das leis garantido pelos direitos humanos. No que tange ao princípio da soberania popular, aponta-se para os direitos de comunicação e participação que asseguram autonomia pública dos cidadãos do Estado; e quanto ao domínio das leis, temos os direitos fundamentais clássicos que garantem a autonomia privada dos membros da sociedade civil. Nesse sentido, o direito - dado o seu caráter instrumental legitima-se como um meio para o asseguramento equânime da autonomia pública e privada (HABERMAS, 2007, pg. 297 - 298). A partir dessas premissas, os direitos humanos passariam ser entendidos, portanto, sob dois anglos:

Em um caso, os direitos humanos deveriam a sua legitimidade ao resultado da autocompreensão ética e da autodeterminação soberana de uma coletividade política; no outro caso, eles deveriam construir limites legítimos, a partir deles mesmos, que vedassem à vontade soberana do povo a usurpação das esferas de liberdade subjetivas intocáveis (HABERMAS, 2001, pg. 147).

Na dialética entre liberalismo e democracia radical, fenômenos intensificados com a Revolução Francesa, a disputa se concentrava em torno do modo como a igualdade pode ser equacionada frente à liberdade, bem como a unidade com a pluralidade, o direito da maioria com o da minoria. Para os liberais a institucionalização jurídica das liberdades iguais devem vir em primeira mão, sendo descritas como direitos subjetivos. Para eles, os direitos humanos gozam de um primado normativo do qual a vontade do legislador democrático subjaz; os direitos humanos permanecem, assim, com status prima facie em relação à democracia e à constituição que divide os poderes. Por sua vez, Habermas (2003, pg. 258 - 259) considera, que o ponto em destaque desta apreciação consiste no vínculo estabelecido entre razão prática e vontade soberana, 
entre direitos humanos e democracia. Para que a razão legitimadora do poder não se anteponha mais à vontade soberana do povo, situando os direitos humanos num estado natural fictício, atribui-se à pratica de legislação autônoma uma estrutura racional peculiar, de tal forma que a vontade unida dos cidadãos só pode manifestar-se na forma de leis gerais e abstratas, é forçada per se a uma operação que exclui todos os interesses não generalizáveis, admitindo apenas as normatizações que garantem a todos iguais liberdades. O exercício da soberania popular garante, pois, os direitos humanos.

Logo, para que intuição ganhe expressão correta, recomenda-se observar o procedimento democrático sob pontos de vistas da teoria dos discursos, que trazem consigo os fenômenos do mundo da vida circunscritos em meio ao pluralismo social e a visões de mundo, de forma a se conferir legitimidade ao processo de criação do direito. Habermas (2007, pg. 300), então, define como válidas tão-somente as regulamentações que contam com a concordância quiçá de todos os envolvidos participantes de um mesmo discurso racional. Tratando-se de discursos e negociações, que se referem ao espaço em que se pode formar uma vontade política racional, então a suposição de racionalidade que deve embasar o processo democrático tem necessariamente de apoiar em um arranjo comunicativo engenhoso. Logo, a elaboração desse procedimento significa que:

A almejada coesão interna entre direitos humanos e soberania popular consiste, assim, em que a exigência de institucionalização jurídica de uma prática civil do uso público das liberdades comunicativas seja cumprida justamente por meio dos direitos humanos. Direitos humanos que possibilitam o exercício da soberania popular não se podem impingir de fora, como uma restrição.

Essa reflexão só elucida os direitos políticos do cidadão, isto é, os direitos de comunicação e de participação que asseguram o exercício da autonomia política e não os direitos humanos clássicos que garantem a autonomia privada dos cidadãos. Os direitos fundamentais que tratam das liberdades subjetivas iguais, bem como os direitos fundamentais que tratam do status de identidade nacional e a ampla proteção jurídica individual são direitos que trazem consigo valores intrínsecos e, dessa forma, cabe a cada cidadão desempenhar esforços para sua real garantia, para que, assim, possam alcançar os objetivos de sua vida privada em igualdade de condições (chances) (HABERMAS, 2007, pg. 300). 
Partindo do pressuposto de uma relação isonômica entre os cidadãos em, que todos, sejam igualmente livres, devem, reciprocamente, conceder uns aos outros, quais espécies de direitos fundamentais, se quiserem regulamentar a sua vida em comum por meio do direito positivo? Neste ponto, Habermas (2001, pg. 148) parte de um princípio em que todos os sujeitos de atos de fala devem arguir a legitimidade daquelas regulamentações com as quais todos os possivelmente atingidos concordariam como participantes de um discurso. Nos discursos, os participantes, à medida que formulam seus argumentos contrafactuais, procuram convencer uns aos outros e, nesse sentido, consequentemente, chegaram num ponto comum (convenção); já nas negociações, os sujeitos buscam tão-somente equacionar seus interesses particulares. Logo se, tais discussões e negociações constituem o campo em que a vontade política racional pode se formar, a suposição de resultados legítimos, que devem fundamentar o procedimento democrático, deve se apoiar, em última instância, num arranjo comunicativo. $\mathrm{O}$ nexo interno que se imagina estar acoplado entre os direitos humanos e a soberania popular consiste, portanto,

No fato de que os direitos humanos institucionalizam as condições de comunicação para a formação da vontade política racional. Direitos que possibilitam o exercício da soberania popular não podem ser impostos a essa práxis como limitações de fora. Esse raciocínio é evidente de modo imediato apenas para os direitos políticos civis, ou seja, para os direitos de comunicação e à participação, mas não para os direitos clássicos à liberdade que garantem a autonomia privada dos cidadãos.

Contudo, quando se busca decidir se é possível (ou não) a institucionalizar, sob forma de direito político dos cidadãos, os pressupostos de comunicação dos quais os sujeitos de atos de fala julgam se é legítimo o direito que eles firmam à luz do princípio discursivo, nesse ponto, o código jurídico precisa estar como tal à disposição. Destarte, faz-se necessário que se crie um status dos sujeitos de direito que pertençam, como portadores de direitos subjetivos, a uma associação voluntária de jurisconsortes e que, efetivamente, façam valer, por meio do ordenamento legal, suas respectivas reivindicações jurídicas. Portanto, uma vez que a autonomia privada venha a ser mitigada, não há que se falar em direito algum e, no mesmo sentido, não existindo direitos fundamentais que asseguram a autonomia privada dos cidadãos, consequentemente. não haverá também o medium para institucionalização jurídica das 
condições que garantem o exercício da autonomia pública no desempenhar do seu papel de cidadãos do Estado (HABERMAS, 2007, pg. 301). A partir dessas considerações, entende-se que, pelo fato de os cidadãos só poderem fazer uso adequado de sua autonomia pública desde que estejam no uso pleno da sua autonomia, ou seja, sejam independentes o bastante em razão duma autonomia privada equanimemente assegurada, entretanto, os mesmo só poderão chegar a uma regulamentação capaz de formular um consenso, desde que façam, adequadamente, o uso de suas autonomias políticas, enquanto cidadãos do Estado; é por isso que, os direitos fundamentais liberais e políticos são indivisíveis.

\section{CONSIDERAÇÕES FINAIS}

Resumidamente, já verificamos em linhas supra, que a ideia do Estado de direito sustentado pelo direito legitimamente instituído exige do poder público uma organização quanto aos seus atos. Nesse sentido, o poder político deve espelhar em seus atos a legitimidade reconhecida na instituição do próprio direito. Simultaneamente, teremos entre o código do direito e o código do poder uma mútua complementação, com o fim de preencher suas respectivas funções. Nessa linha de entendimento, observamos que a interligação complexa entre direito vinculante e poder político abre possibilidade à instrumentalização do direito, no sentido de seu emprego estratégico. Sendo assim, no Estado de direito, qualquer uso publicamente autorizado do poder reclama uma legitimidade conferida nos termos do direito legitimamente instituído.

No sistema da administração pública, encontra-se um poder que lhe fora conferido para o exercício das suas prerrogativas (licença, autorização, concessão, permissão, etc.) enquanto administração pública. Esse poder precisa regenerar-se a cada passo a partir do poder comunicativo. Dessa forma, o direito não é visto tão-somente como algo constitutivo para o código do poder que dirige o processo de administração, constatando-se que o direito forma, portanto e simultaneamente, o médium para a transformação do poder comunicativo em administrativo. Essas ligações conceituais de Habermas são trabalhadas a partir de duas perspectivas: na primeira, enfatiza o princípio da soberania popular para introduzir os princípios do Estado de direito; na 
segunda, procura desenvolver esses princípios na perspectiva da institucionalização jurídica da rede que abarca discursos e negociações.

No princípio da soberania popular, em que se concebe a ideia de que todo poder do Estado emana do povo, o direito subjetivo à participação com oportunidades iguais na formação democrática da vontade, consente com a possibilidade jurídico-objetiva de uma prática institucionalizada de autodeterminação dos cidadãos pelo uso da razão comunicativa. Uma vez reconhecida essa prática por todos, como um processo de resolução de problemas sociais e políticos, sua força de legitimação tem como fundamento um processo democrático destinado a garantir um tratamento racional para os problemas arrostados. Da lógica dos discursos, resulta também o princípio do pluralismo político que se faz expressar dentro e fora dos corpos representativos. Nesse sentido, o princípio da soberania popular exige uma estruturação discursiva de arenas públicas nas quais sistemas de comunicação anônimos destacam-se do nível concreto de simples interações. Ora, essa informalidade de sistemas de comunicação anônimos visam a complementar a formação da opinião e da vontade parlamentar não preenchida integralmente. As arenas públicas devem sua efetividade na formação dos discursos inerentes aos direitos fundamentais, sem os quais não se pode proporcionar aos atores o fluxo livre de opiniões, pretensões de validade e tomadas de posições.

Esses direitos, reciprocamente atribuídos pelos cidadãos numa dimensão horizontal (cidadão - a - cidadão), precisam ser ainda mais estendidos, a partir do momento em que se constitui um poder executivo, à dimensão vertical entre as relações dos cidadãos com o Estado. Esses direitos, interpretados como "liberais", formam - num sentido mais estrito do ponto de vista histórico - o núcleo das declarações dos direitos humanos. A separação entre Estado e sociedade, busca ressaltar uma garantia jurídica de forma a instaurar uma autonomia social, e assim conferir a cada cidadão iguais oportunidades ao uso de seus direitos de participação política e de comunicação. Esse princípio exige a instauração de uma sociedade civil que direcione - democraticamente as relações de associações e a própria cultura política desenvolvida. O Estado não pode ser confundido com a sociedade, exercendo papéis ou participando de negociações que colocariam ambos no mesmo lugar. A sociedade civil, por si só, precisa equalizar e neutralizar a divisão desigual de posições sociais de poder e dos potenciais de poder daí derivados, objetivando, com isso, esperar que o poder social possa impor-se na medida 
em que possibilita, sem restringir, o exercício da autonomia dos cidadãos. Com a expressão poder social, Habermas busca apontar a possibilidade de um ator impor interesses próprios na esfera das relações sociais, mesmo que esses interesses possam resistir a interesses alheios.

Em Direito e Democracia, Habermas afirma que a idéia, segundo a qual o poder do Estado pode elevar-se acima das forças sociais como um poder neutro, não passa de uma ideologia. O processo político que resulta da sociedade civil, necessariamente deve adquirir uma parcela de autonomia em relação a potenciais do poder já fixados na estrutura social (poder das associações, modo de financiamento do partido), de modo que, o sistema político não se degrade e, assim, venha a assumir forma de um partido como os demais, seja no papel do poder executivo, seja no poder de sanção. O Estado não pode perder de vista os fins para os quais fora instituído; sua legitimidade deriva do seu real compromisso de se fazer cumprir a justiça política pela implantação de um direito legitimamente normatizado; logo, o Estado deve acautelar-se, de sobremodo, para não comprometer seus fins nos instantes em que participa de arranjos corporativistas. O princípio da separação entre Estado e sociedade tem como lema conservar a ideia duma organização do Estado de direito, pretendendo com isso, fortalecer à auto-organização política autônoma de uma comunidade que se constitui e se mantém, via sistema de direitos, como uma associação de membros livres e iguais do direito. A instituição do Estado de direito deve garantir o exercício efetivo da autonomia política de cada cidadão socialmente autônomo, de forma que o poder comunicativo de uma vontade formada racionalmente possa surgir e sua expressão seja reconhecida em programas legais, alcançando a sociedade na totalidade da sua esfera via aplicação racional da implementação administrativa de programas legais, desenvolvendo plenamente sua força de integração social - com a persecução de seus fins e estabilização de expectativas e da realização dos interesses públicos.

\section{RATIONALITY OF LAW AND HUMAN CONDITION: ON THE INTERWEAVING OF LAW, POLITICAL AND MORAL}

\section{Abstract}


The proposed Habermas seeking to assert the legitimacy of the democratic constitutional state based on human rights aims to establish an internal connection between an effective democracy - political exercise - and the right. Therefore, it is necessary to formulate a political concept of legitimacy of orders characterized by the organization of state power, which follows pegged to the law legitimately established. Whereas the medium of state power is constituted in the form of law, policies seek orders in the legitimacy of the claimed right, its vigor. This article focuses on research examining the theoretical deficit and possibilities for implementation of the democratic exercise, recognition, and to evaluate the completeness relationship between politics and law. To this end this article drawing on the thought of Habermas sees the figure of the modern positive law, the possibility of assimilating - via communicative action - the tension between facticity and validity. This article returned their attention to the core problem that embraces the possibilities of social reproduction installed in the living world, seeking to assert the legitimacy of the right to view the proposal established the ideals of a democratic state.

Keywords: Human Dignity. Struggle for Recognition. Emancipation. Democratic state.

\section{REFERÊNCIAS}

CHAMON J. Lúcio Antonio. Filosofia do direito na alta modernidade: Incursões teóricas em Kelsen, Luhmann e Habermas. Rio de Janeiro: Lúmen Júris, 2005.

HABERMAS, Jürgen. A inclusão do outro: estudos de teoria política. 3. "ed.”. "Tradução: Paulo AstorSoethe". São Paulo: Loyola. 2007.

Mudança estrutural da esfera Pública. 2. “ed.”. “Tradução: Flávio R. Kothe”. Rio de Janeiro: Tempo Brasileiro. 2003.

Direito e democracia: entre facticidade e validade. I. 2. "ed.". “Tradução: Flávio Beno Siebeneichler”. Rio de Janeiro: Tempo Brasileiro. 2003.

Direito e democracia: entre facticidade e validade. II. 2. "ed.”. "Tradução: Flávio Beno Siebeneichler". Rio de Janeiro: Tempo Brasileiro. 2003.

Era das transições. "Tradução: Flávio BenoSiebeneichler". Rio de Janeiro: Tempo Brasileiro, 2003.

A constelação pós-nacional: Ensaios políticos. "Tradução: Márcio Seligmann Silva”. São Paulo: Littera Mundi, 2001.

O discurso filosófico da modernidade. “Tradução: Ana Maria Bernado" Et all. Lisboa: Dom quixote, 1990.

Teoria de la acción comunicativa. Racionalidad de La acción y racionalización social. Trad. Manuel Jimenez Redondo. Tomo I. Madrid: Taurus, 1987.

HONNETH, A. Luta por reconhecimento: a gramática moral dos conflitos sociais. Trad: Luiz Repa. São Paulo: Ed. 34, 2003. 
MATTOS, P. Recognition, between Justice and Identity. São Paulo: Lua Nova. 2004 .

MEAD, G. H. Espiritu, persona y sociedad. Ciudad de México : Paidós. 1993.

PENITENTE, Luciana Aparecida de Araújo. Habermas e Mead: A linguagem como Médium de Socialização. (Orgs). Clélia Aparecida Martins e José Geraldo Poker. O pensamento de Habermas em questão. Marilia: Oficina Universitária Unesp, 2008.

PIZZI, Jovino. Desafios Éticos e Políticos da Cidadania. Ensaios de Ética e Filosofia Política. Ijuí: Unijuí. 2006.

POZZOLI, Lafayette. Maritain e o Direito. São Paulo: Loyola. 2001.

POKER, José Geraldo A.B. A democracia e o problema da racionalidade. (orgs.) Clélia Aparecida Martins e José Geraldo Poker. O pensamento de Habermas em questão. Marilia: Oficina Universitária Unesp. 2008.

SCHUMACHER, Aluisio Almeida. Comunicação e democracia: fundamentos pragmático-formais e implicações jurídico-políticas da teoria da ação comunicativa. 2000. 245 f. Tese (Doutorado em Ciências Política). Departamento de Ciências Política do Instituto de Filosofia e Ciências Humanas da Universidade Estadual de Campinas. Campinas, 2000.

SILVA, Luciano Braz. Estado democrático de direito, direitos humanos e democracia: perspectivas racional-discursivas no pensamento de Habermas. Revista Direito Mackenzie, São Paulo, v. 6, n. 2, 2014, pg. 230-250.

Legitimidade do poder e exercício político: facticidade e validade do direito. Perpectivas para uma análise normativa e instrumental. EM TEMPO Marília - v. 12 - 2013, pg. 219-237.

A função do direito no mundo da vida: LINGUAGEM, EMANCIPAÇÃO E RECONHECIMENTO. Revista Direito e Liberdade - Santa Catarina - v. 15, n. 3, 2013, pg. 71-95.

O reconhecimento no Estado Democrático de Direito: perspectivas da filosofia de Habermas para efetividade da Democracia e dos Direitos Humanos. Revista Direito Práxis, Rio de Janeiro, v.4, n.7, 2013, pg. 122-152.

SOUZA, J. Charles Taylor e a teoria crítica do reconhecimento. Brasília: UnB, 2000.

Uma teoria crítica do reconhecimento. São Paulo: Lua Nova, 2000.

TAYLOR, C. The Politics of Recognition. In: GUTMANN, A. (ed.). Multiculturalism : Examining the Politics of Recognition. Princeton : Princeton University. 1994 
As fontes do self: a construção da identidade moderna. Tradução de Adail U. Sobral; Dinah de A. Azevedo. São Paulo: Loyola, 1997.

WERLE, Denílson L; SOARES, Mauro V. Política e direito: a questão da legitimidade do poder político no Estado Democrático de Direito. (Org.) Marcos Nobre, e Ricardo Terra. Direito e democracia: Um guia de leitura de Habermas. São Paulo: Malheiros. 2008.

Trabalho enviado em 20 de agosto de 2014. Aceito em 11 de fevereiro de 2015. 